\title{
Bilateral striopallidodentate calcinosis secondary to postsurgical hypoparathyroidism
}

\author{
Dong-Rong Tsai, ${ }^{1}$ Shih-Horng Huang, ${ }^{2}$ Sheng-Hsiang Lin ${ }^{3,4}$
}

${ }^{1}$ Department of Neurology, New Taipei City Hospital, New Taipei, Taiwan

${ }^{2}$ Department of Surgery, New Taipei City Hospital, New Taipei, Taiwan

${ }^{3}$ Department of Internal Medicine, New Taipei City Hospital, New Taipei, Taiwan ${ }^{4}$ Department of Respiratory Therapy, Fu-Jen Catholic University, New Taipei, Taiwan

\section{Correspondence to} Dr Sheng-Hsiang Lin, linsh01@gmail.com
To cite: Tsai D-R, Huang $S$ H, Lin S-H. BMJ Case Rep Published online: [please include Day Month Year] doi:10.1136/bcr-2013200591

\section{DESCRIPTION}

Bilateral striopallidodentate calcinosis (BSPDC) is characterised by calcifications of bilateral basal ganglia and dentate nuclei with or without thalamus, subcortical white matter and cerebellum involvement. ${ }^{1}$ A computed tomography (CT) is useful in diagnosing and determining the extent of BSPDC. ${ }^{1}$ Here we report a 48 -year-old woman presenting to the emergency department with a sudden onset conscious loss followed by general convulsions. She had undergone a total thyroidectomy for a benign thyroid goitre 20 years ago. A marked decrease in the serum calcium level $(4.7 \mathrm{mg} / \mathrm{dL})$ was noted. The diagnoses of hypoparathyroidism and primary hypothyroidism were also confirmed thereafter. A non-contrast head CT (figure 1) revealed symmetric intracranial calcifications, including subcortical white matter, thalami, basal ganglia, caudate nuclei and cerebellums. After the correction of hypocalcaemia with intravenous
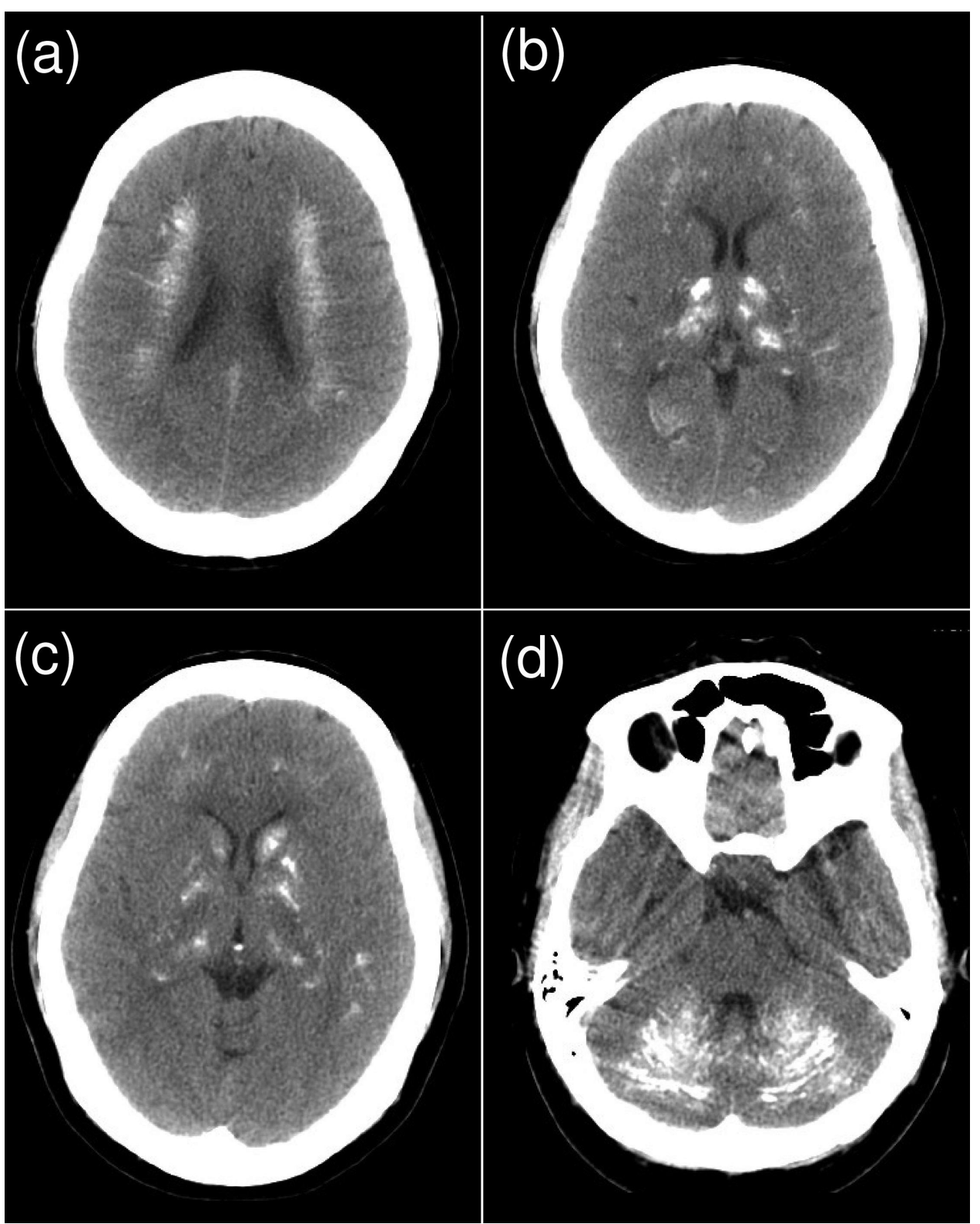

Figure 1 Non-contrast head CT showing symmetric calcifications in subcortical white matter (A), thalami (B), basal ganglia (C), dentate nuclei and cerebellums (D). 
calcium gluconate, no more seizures occurred and she was discharged 8 days later with long-term oral calcium, calcitriol and thyroid hormone supplement.

About $1 \%$ of patients who receive a total thyroidectomy would have permanent hypoparathyroidism, and measuring serum parathyroid hormone and calcium levels postoperatively is mandatory. ${ }^{2}$ BSPDC, also named as Fahr's disease, may be an inherited disease or secondary to a variety of disorders, such as hypoparathyroidism, hyperparathyroidism, congenital brain anomalies and systemic lupus erythematosus. ${ }^{1}$ Among patients with BSPDC, a greater extent of brain calcification indicates a higher probability of having neurological symptoms, of which parkinsonism is the most important presentation. ${ }^{3}$ Given the irreversibility of BSPDC, hypoparathyroidism should be treated early and a head CT should be considered for patients with neurological symptoms. ${ }^{13}$
Competing interests None.

Patient consent Obtained.

Provenance and peer review Not commissioned; externally peer reviewed.

\section{REFERENCES}

1 Manyam BV. What is and what is not 'Fahr's disease'. Parkinsonism Relat Disord 2005;11:73-80.

2 Asari R, Passler C, Kaczirek K, et al. Hypoparathyroidism after total thyroidectomy: a prospective study. Arch Surg 2008;143:132-7.

3 Manyam BV, Walters AS, Narla KR. Bilateral striopallidodentate calcinosis: clinical characteristics of patients seen in a registry. Mov Disord 2001;16:258-64.

\section{Learning points}

A substantial proportion of patients who receive a thyroidectomy would develop hypoparathyroidism.

- Bilateral striopallidodentate calcinosis is characterised by calcifications of the bilateral striata, pallida and dentate nuclei with or without other intracranial calcifications.

- Bilateral striopallidodentate calcinosis may be inherited or secondary to a variety of diseases including parathyroid disorders.

Copyright 2013 BMJ Publishing Group. All rights reserved. For permission to reuse any of this content visit http://group.bmj.com/group/rights-licensing/permissions.

BMJ Case Report Fellows may re-use this article for personal use and teaching without any further permission.

Become a Fellow of BMJ Case Reports today and you can:

- Submit as many cases as you like

- Enjoy fast sympathetic peer review and rapid publication of accepted articles

- Access all the published articles

- Re-use any of the published material for personal use and teaching without further permission

For information on Institutional Fellowships contact consortiasales@bmjgroup.com

Visit casereports.bmj.com for more articles like this and to become a Fellow 